\title{
Evaluation of effects of sustained decadal precipitation manipulations on soil carbon stocks
}

\author{
Mats Fröberg • Paul J. Hanson • \\ Donald E. Todd • Dale W. Johnson
}

Received: 25 October 2007 / Accepted: 27 April 2008 / Published online: 18 June 2008

(C) The Author(s) 2008

\begin{abstract}
Throughout a 13 year period, the Throughfall Displacement Experiment sustained both increased (+33; wet) and decreased $(-33 \%$; dry) throughfall into an upland oak forest in Tennessee. Organic (O) horizon carbon (C) stocks were measured at several occasions before, during and after the experiment and mineral soil $\mathrm{C}$ stocks before and after the experiment. In the $\mathrm{O}$ horizon, higher $\mathrm{C}$ stocks were observed in the dry treatment compared to the ambient and wet, attributable to a combination of enhanced litter inputs and reduced decomposition. No precipitation treatment effects on mineral soil $\mathrm{C}$ stocks were found to a depth of $60 \mathrm{~cm}$. Conversely, long-term reductions in surface mineral soil $\mathrm{C}$ stocks were surprisingly high for all treatments (3.5-2.7\% $\mathrm{C}$ in the $0-15 \mathrm{~cm}$ layer and from 0.6 to $0.5 \%$ in the $15-30 \mathrm{~cm}$ layer) over the duration of the experiment. A clear explanation for this temporal trend in $\mathrm{C}$ storage was not readily apparent.
\end{abstract}

M. Fröberg · P. J. Hanson · D. E. Todd

Environmental Sciences Division, Oak Ridge National

Laboratory, Oak Ridge, TN 37831-6422, USA

M. Fröberg ( $\square)$

Department of Soil and Environment, The Swedish

University of Agricultural Sciences, P.O. Box 7001,

75007 Uppsala, Sweden

e-mail: mats.froberg@sml.slu.se

D. W. Johnson

Natural Resources and Environmental Science, University of Nevada, Reno, NV 89557, USA
Keywords Soil organic carbon · Forest soils · Precipitation

\section{Introduction}

Climate models predict shifts in both temperature and precipitation worldwide (Meehl et al. 2007) with great potential to affect virtually all ecosystem processes including biogeochemical cycles controlling the carbon cycle. Precipitation is predicted to increase in the future in northern North America, whereas a decrease is projected for the southern part of the continent (Christensen et al. 2007). Shifts in precipitation, in particular, have the potential to produce effects on the ecosystem and soil C stocks, but the influence of precipitation change has not been as intensely studied as the corresponding effects of warming on soil C.

Changes in precipitation may affect $\mathrm{C}$ stocks in several different ways and interactions between factors must be considered when predicting the effects of a shift in precipitation regime on the $\mathrm{C}$ cycle. Numerous studies have shown that decomposition rates are lower during drier soil conditions independent of a change in temperature (e.g. Reichstein et al. 2003; Borken et al. 2006). Soil moisture may, however, affect microbial activity negatively both during dry conditions by limiting the availability of water, and during wet conditions by limiting diffusion of $\mathrm{O}_{2}$ through the soil. The amount and timing of precipitation, therefore, 
has the potential to impact the decomposition of soil organic carbon and thereby the carbon stocks (Heimann and Reichstein 2008; Mikha et al. 2005). Nitrogen mineralization rates are also affected by soil moisture. The close coupling between the nitrogen and carbon cycles suggests that interactions between these cycles may change the response of the ecosystem to climate in unexpected ways (Aber et al. 1991; Garten et al. 1994; Heimann and Reichstein 2008). Short-term responses to dynamic climate conditions (i.e. weather) may result in cumulative impacts on element cycling with concomitant impacts on ecosystem net primary production. The highly dynamic responses to weather conditions are difficult to extrapolate to long-term ecosystem responses to changes in climatic conditions (Hyvönen et al. 2007). Over multiple years of precipitation change, physiological acclimation, the distribution of live and dead carbon and mineral pools can be expected to occur. For example, dryer conditions have been found to result in higher root: shoot ratio (Joslin and Wolfe 1998; Dress and Boerner 2001) and may thereby affect the size of $\mathrm{C}$ inputs to the soil and the distribution between aboveground and belowground inputs. Shifts in vegetation composition may also occur with time following changes in biogeochemical cycling processes driven by precipitation change, but such changes proceed only slowly over a time-scale of centuries (Loehle and LeBlanc 1996). The different time scales at which the ecosystems respond to the availability of water must be considered when predicting long-term responses to changes in precipitation.

In this study we take advantage of a long-term throughfall manipulation experiment (Hanson et al. 2003a) to understand how changes in precipitation may influence soil organic carbon stocks on a decadal time-scale. The throughfall displacement experiment (TDE) was established to develop mechanistic understandings of adjustments of forest ecosystems to changes in precipitation that may occur in a changing climate. The study was originally established in 1993 to address a wide range of precipitation change responses to inform plant and biogeochemical cycling response mechanisms for the improvement of ecosystem models in the face of future climatic change. Current climate projections suggest only small precipitation changes at this eastern United States site by 2100 (Christensen et al. 2007). Response of soil organic carbon to climate change was not the primary focus of the TDE study, but in the years after the establishment of the experiment an awareness of the importance of the status of soil carbon pools in the context of the global carbon cycle has grown. The presence of the long-term record of soil carbon changes afforded by the TDE study provides a unique opportunity to study $\mathrm{C}$ stocks under changing precipitation regimes. In a previous paper (Johnson et al. 2008), we describe changes in mineral soil $C$ and nutrient concentrations and contents over the sampling period. In this paper, we expand upon the mineral soil data base with additional data on $\mathrm{O}$ horizon and large woody debris data and conduct a much more detailed analysis of the effects of treatment on the $\mathrm{C}$ cycles.

Reduced and elevated throughfall inputs were hypothesized to reduce and increase decomposition rates of the soil organic matter, respectively, and therefore have an effect on the soil organic carbon stocks. The highest $\mathrm{C}$ stocks to be expected with drying conditions, and the lowest with additional precipitation inputs. Furthermore differences between treatments were hypothesized to be most pronounced in the $\mathrm{O}$ horizon with responsiveness decreasing or disappearing with depth, due to the presence of more stable $\mathrm{C}$ pools in deeper soils.

\section{Materials and methods}

Site description

The experiment was located on the Walker Branch Watershed $\left(35^{\circ} 58^{\prime} \mathrm{N}\right.$ and $\left.84^{\circ} 17^{\prime} \mathrm{W}\right)$, a part of the U.S. Department of Energy's (DOE's) National Environmental Research Park near Oak Ridge, Tennessee (Johnson and Van Hook 1989). Longterm (1951-2006) mean annual precipitation was $1,344 \mathrm{~mm}$ and mean annual temperature was $14.3^{\circ} \mathrm{C}$. Precipitation is on average evenly distributed throughout the year. The acidic forest soils $(\mathrm{pH}$ 3.5-4.6) are primarily typic Paleudults. The experimental study area within the watershed was chosen because of its uniform slope, consistent soils, and a reasonably uniform distribution of vegetation. Early aerial photographs show that the TDE study area was forested in the late 1930s, but several large dominant trees show open growth characteristics an indication of some harvesting before that time (URL:http://tde.ornl.gov/landuse.html). 
A description of the upland oak vegetation characteristics of this site can be found in Hanson et al. (2001, 2003a). Quercus spp. and Acer spp. were the major canopy dominants with Liriodendron tulipifera L. a canopy dominant on lower slope positions, and Nyssa sylvatica Marsh. and Oxydendrum arboreum [L.] D.C. the predominant species occupying midcanopy locations.

\section{Experimental system}

The experimental system and its performance were described in detail by Hanson et al. (2001, 2003a). Manipulations of throughfall amounts reaching the forest floor were made by passively transferring a fraction of canopy throughfall from one experimental plot to another over 13 years from July 1993 through June of 2006 . There were three $(80 \times 80 \mathrm{~m})$ experimental plots: one wet, one dry, and one ambient. Each plot was divided into $8 \times 8 \mathrm{~m}$ subplots that served as potential locations for repetitive measurements of organic layer and mineral soil characteristics. An $8 \mathrm{~m}$ buffer zone around the edge of all plots $(16 \mathrm{~m}$ between plots) was treated but not used for observations of response. On the dry plot, throughfall precipitation was intercepted in $\sim 1,900$ below-canopy troughs $(0.3 \times 5 \mathrm{~m})$ made of greenhouse grade polyethylene that was suspended at an angle above the forest floor ( $\sim 33 \%$ of the ground area was covered). Intercepted throughfall was transferred by gravity flow across the ambient plot and distributed onto the wet treatment plot using a shallow gravity gradient through paired drip holes spaced approximately $1 \mathrm{~m}$ apart along each of the twenty $80 \mathrm{~m}$ distribution pipes covering the wet treatment study area. The effect of manipulations of throughfall on soil moisture status was confirmed by TDR measurements at 310 sampling locations distributed over the manipulated area. Additional experimental details including results from TDR measurements through 2000 can be found in Hanson et al. (2003a) and treatment performance data from 1993 to 2006 are available online (URL:http://tde.ornl.gov). Hanson et al. (1995) demonstrated that the impact of trough infrastructure on understory microclimate was minimal.

The experimental area was located on a southern aspect at the upper divide of the watershed so that lateral flow of water into the plots from upslope did not occur.
Measurements of organic and mineral soil carbon pools

Organic horizons were sampled throughout the study period using identical methods in late January 1992 (pre-treatment), and February of 1999, 2002, 2004, and 2006. General sampling locations were designated in protected areas of each treatment plot along upper, middle and lower slope transects in undisturbed areas, away from foot traffic. Repeated collections within each of the designated sampling areas were done in a sub-area that had never been previously sampled due to the consumptive nature of the organic layer measurements. Sampling for each campaign was undertaken at five locations per transect in each treatment area for a total of 15 sampling locations for each of the wet, ambient, and dry treatment areas.

Organic horizons were sampled within $0.25 \mathrm{~m}^{2}$ circular plots. Coarse twigs and large pieces of nonfoliar litter were collected first followed by the separation of the components of the $\mathrm{O}$ horizon (Oi, Oe, $\mathrm{Oa}$ ). The $\mathrm{C}$ stocks of the Oe and Oa horizons are presented together, because the Oe or Oa horizons were too thin or difficult to separate in a replicable manner. All organic horizon samples were immediately oven dried for $48 \mathrm{~h}\left(70^{\circ} \mathrm{C}\right)$ and dry mass was determined. The organic horizon samples were subsequently coarse ground in a large Wiley mill without further separations (i.e. fine roots of the Oa horizon were not removed). Sub-samples of the homogenized coarseground material were further ground to 20 mesh in a Tecator Cyclotec sample mill (Tecator, Herndon, $\mathrm{VA}$ ) prior to the evaluation of $\mathrm{C}$ and other element concentrations.

Mineral soils were sampled in January/February 1992 and again in January/February 2006. Samples were collected at $15 \mathrm{~cm}$ increments to a depth of $90 \mathrm{~cm}$, but variable rock content only allowed full analysis to the $60 \mathrm{~cm}$ depth. In each treatment area, soil coring was conducted at seven locations $8 \mathrm{~m}$ apart along seven transects up and down the natural SE facing slope for a total of 49 samples per treatment area. In 1992 sampling was done with a $6.6 \mathrm{~cm}$ diameter bucket auger and in 2006 with a gasoline powered $10 \mathrm{~cm}$ diameter diamond bit coring tool. Field collected mineral soil samples were frozen until processed during the year of sampling. Mineral soil processing included sieving to extract roots and rocks 
(8-mm sieve) for later weighing. The coarse sieved material was oven dried $\left(70^{\circ} \mathrm{C}\right)$, and subsequently processed through a $2 \mathrm{~mm}$ sieve. All dried soil samples were archived in sealed glass containers for simultaneous analysis of all pre- and post-treatment samples in 2006.

Dry samples of organic horizons and soil were analyzed for total $\mathrm{C}$ and $\mathrm{N}$ on a LECO CN-2000 (LECO Corporation, St. Joseph, Michigan) using secondary standards traceable to NIST reference materials. Mineral analysis was performed by microwave-acid digestion with digests being analyzed by ICP emissions spectrograph (Thermo Jarell-Ash model 61E ICP).

Data for the organic and mineral soils are presented as both dry mass and carbon content per unit soil area.

\section{Statistical analyses}

The unreplicated nature of the TDE experimental manipulation plots is not ideal, but the resulting pseudoreplication is recognized as a reasonable approach when costly large-scale experimental field designs are undertaken (Eberhardt and Thomas 1991), nevertheless, recognizing the issue of pseudoreplication is important (Hurlbert 1984). To minimize potential confounding of site and imposed treatments the unreplicated experimental plots were selected based on pre-treatment characterization of the uniform nature of site environmental parameters (including climatic conditions), the identification of comparable control areas, and supported by substantial pretreatment sampling of the variables of interest (Hanson et al. 2003a). Judicious site selection (i.e. uniform vegetation, soil type, and slope) minimizes the possibility of confounding site with treatment in this experiment. Pre-treatment variability in vegetation, soil and slopes was consistent across the treatment areas.

Individual organic layer $(n=15)$ and soil mineral samples $(n=49)$ were treated as spatially-separated observations having independent soil water and climatic conditions for the purpose of evaluating treatment effects. Treatment effects for soil C concentration and soil $\mathrm{C}$ stocks of the mineral soil and dry matter for the organic horizon layers (Oi, OeOa, and woody material) were evaluated using univariate covariance ANOVA which helped to minimize pretreatment biases. Measured pretreatment values for mineral soil $\mathrm{C}, \mathrm{N}$ and $\mathrm{CN}$ ratio were used as the covariates for the mineral soil analyses, and the covariate for organic layer dry matter pools included the mean of data from several sampling periods prior to the development of treatment effects. Treatment effects on element concentrations and stocks of the organic and woody litter layers were evaluated with univariate ANOVA as no appropriate pre-treatment covariate data were available. All statistical analyses were executed on SPSS 16.0 for Mac OS X.

\section{Results}

O horizon

Mean $\mathrm{C}$ concentrations of the organic and mineral soil for different years and treatments are given in Table 1 . O horizon dry mass and $\mathrm{C}$ stocks are presented in Fig. 1. Significant treatments effects were observed in the $\mathrm{O}$ horizon standing dry matter pools by treatment and over time. Conversely, neither treatment nor time had a significant effect on $\mathrm{C}$ concentrations of the measured soil organic horizons.

Carbon concentration data for the Oe/Oa and $\mathrm{Oi}$ were not available for 1992 (rodent damaged archive material), but the relationships between mass and $\mathrm{C}$ stocks for the other years $\left(R^{2}=0.89\right.$ and 0.98 , respectively) make us confident that the use of litter mass to approximate $\mathrm{C}$ stocks was appropriate. There was no indication of pre-treatment biases in $\mathrm{C}$ stocks between treatments in either the $\mathrm{Oi}$ or the combined Oe/Oa horizons.

No significant treatment effects were observed on mass or $\mathrm{C}$ stocks in the Oi horizon at any point in time during 13 years of manipulation (Fig. 1). Average C stock of the Oi horizon was $0.16 \mathrm{~kg} \mathrm{C} \mathrm{m}^{-2}$ at the end of the experiment.

Higher Oe/Oa C stocks were observed in the dry treatment than in the wet and ambient in the majority of sampled years (Fig. 1). At the end of the experiment $\mathrm{C}$ stocks in the Oe/Oa horizon was $0.59 \mathrm{~kg}$ $\mathrm{C} \mathrm{m}^{-2}$ in the dry treatment and 0.42 and $0.43 \mathrm{~kg}$ $\mathrm{C} \mathrm{m}^{-2}$ in the ambient and wet treatments, respectively. Johnson et al. (2002) reported significant treatment effects on Oe/Oa mass with corresponding differences in carbon stocks by $1999(p<0.01)$ after 6 years of manipulation. The treatment effect was, however, not evident when evaluated in 2002, but 
Table 1 Carbon concentration $(\%)$ of the organic and soil mineral horizons by layer or depth, collection year and precipitation treatment

a na = not available. 1992 organic layers samples were archived after dry mass assessments, but damaged by rodent activity while awaiting $\mathrm{C}$ analysis. Mineral soil samples were only collected in 1992 and 2006

b Mineral soil data from Johnson et al. (2008)

\begin{tabular}{|c|c|c|c|c|c|}
\hline & 1992 & 1999 & 2002 & 2004 & 2006 \\
\hline \multicolumn{6}{|l|}{ Oi horizon } \\
\hline Wet & $\mathrm{na}^{\mathrm{a}}$ & $47.5 \pm 0.3$ & $45.9 \pm 0.4$ & $45.4 \pm 0.3$ & $48.3 \pm 0.4$ \\
\hline Ambient & na & $45.5 \pm 0.9$ & $45.2 \pm 0.2$ & $45.4 \pm 0.3$ & $47.8 \pm 0.2$ \\
\hline Dry & na & $47.6 \pm 0.2$ & $46.5 \pm 0.4$ & $45.5 \pm 0.2$ & $48.2 \pm 0.2$ \\
\hline \multicolumn{6}{|l|}{ Oe horizon } \\
\hline Wet & na & na & $43.5 \pm 1.0$ & $42.9 \pm 0.5$ & $46.8 \pm 0.6$ \\
\hline Ambient & na & na & $42.3 \pm 1.1$ & $41.3 \pm 0.8$ & $44.4 \pm 0.6$ \\
\hline Dry & na & na & $43.5 \pm 1.2$ & $41.5 \pm 0.7$ & $45.7 \pm 0.5$ \\
\hline \multicolumn{6}{|l|}{ Oa horizon } \\
\hline Wet & na & na & $34.2 \pm 1.8$ & $29.0 \pm 1.1$ & $34.7 \pm 1.2$ \\
\hline Ambient & na & na & $31.8 \pm 1.4$ & $27.3 \pm 1.3$ & $26.6 \pm 0.8$ \\
\hline Dry & na & na & $32.9 \pm 1.9$ & $27.7 \pm 1.4$ & $31.0 \pm 1.5$ \\
\hline \multicolumn{6}{|c|}{ OeOa combined } \\
\hline Wet & na & $36.8 \pm 1.5$ & na & na & na \\
\hline Ambient & na & $32.3 \pm 1.3$ & na & na & na \\
\hline Dry & na & $35.4 \pm 0.8$ & na & na & na \\
\hline \multicolumn{6}{|c|}{$0-15 \mathrm{~cm} \mathrm{soil}^{\mathrm{b}}$} \\
\hline Wet & $3.6 \pm 0.1$ & na & na & na & $2.8 \pm 0.1$ \\
\hline Ambient & $3.3 \pm 0.1$ & na & na & na & $2.6 \pm 0.1$ \\
\hline Dry & $3.5 \pm 0.2$ & na & na & na & $2.9 \pm 0.2$ \\
\hline \multicolumn{6}{|c|}{$15-30 \mathrm{~cm} \mathrm{soil}^{\mathrm{b}}$} \\
\hline Wet & $0.64 \pm 0.04$ & na & na & na & $0.56 \pm 0.04$ \\
\hline Ambient & $0.65 \pm 0.05$ & na & na & na & $0.52 \pm 0.05$ \\
\hline Dry & $0.63 \pm 0.04$ & na & na & na & $0.51 \pm 0.06$ \\
\hline \multicolumn{6}{|c|}{$30-45 \mathrm{~cm} \mathrm{soil}^{\mathrm{b}}$} \\
\hline Wet & $0.30 \pm 0.02$ & na & na & na & $0.31 \pm 0.03$ \\
\hline Ambient & $0.31 \pm 0.03$ & na & na & na & $0.31 \pm 0.03$ \\
\hline Dry & $0.34 \pm 0.03$ & na & na & na & $0.33 \pm 0.03$ \\
\hline \multicolumn{6}{|c|}{$45-60 \mathrm{~cm} \mathrm{soil}^{\mathrm{b}}$} \\
\hline Wet & $0.23 \pm 0.02$ & na & na & na & $0.30 \pm 0.03$ \\
\hline Ambient & $0.19 \pm 0.01$ & na & na & na & $0.22 \pm 0.02$ \\
\hline Dry & $0.19 \pm 0.01$ & na & na & na & $0.24 \pm 0.02$ \\
\hline
\end{tabular}

diameter. This fraction contributed to just over $100 \mathrm{~g}$ $\mathrm{C} \mathrm{m}^{-2}$ or about $15 \%$ of the total amount of $\mathrm{C}$ in the forest floor. These data will not be discussed further, but are presented in Table 2 for reasons of completeness and future reference.

\section{Mineral soil}

As noted previously (Johnson et al. 2008), no effects of precipitation treatment were observed on the mineral soils at any depth (Fig. 2). A surprising decrease in mineral soil C stocks, however, was observed between 1992 and 2006 in the 0-15
No significant treatment effects or temporal patterns were observed for coarse woody litter less than $3 \mathrm{~cm}$ 
Fig. 1 Dry mass (left column; $\mathrm{g} \mathrm{dm} \mathrm{m}^{-2}$ ) and carbon stock (right column; $\mathrm{g} \mathrm{C}$ $\mathrm{m}^{-2}$ ) for the $\mathrm{Oi}$ and $\mathrm{Oe} / \mathrm{Oa}$ horizons $\left(\mathrm{g} \mathrm{m}^{-2}\right)$ at TDE from 1992 to 2006. Error bars represent standard error of the replicate samples within the defined treatments
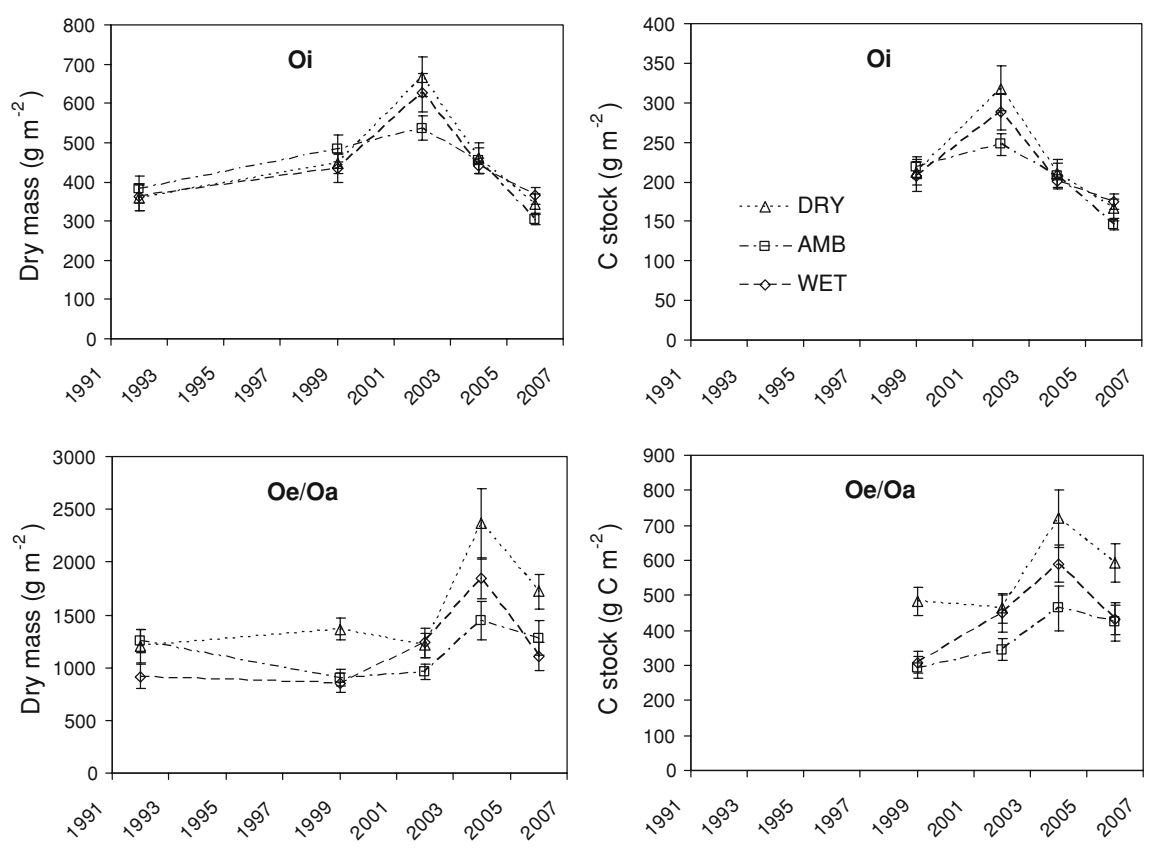

Table 2 Coarse woody dry mass in the organic layers, carbon concentration and carbon content by year and precipitation treatment

\begin{tabular}{|c|c|c|c|c|}
\hline & 1992 & 1999 & 2004 & 2006 \\
\hline Woody dry matter & g d.m. $\mathrm{m}^{-2}$ & g d.m. $\mathrm{m}^{-2}$ & g d.m. $\mathrm{m}^{-2}$ & g d.m. $\mathrm{m}^{-2}$ \\
\hline Wet & $300 \pm 98$ & $163 \pm 14$ & $259 \pm 52$ & $251 \pm 32$ \\
\hline Ambient & $140 \pm 26$ & $159 \pm 26$ & $235 \pm 34$ & $204 \pm 23$ \\
\hline Dry & $262 \pm 77$ & $283 \pm 31$ & $483 \pm 91$ & $246 \pm 40$ \\
\hline Woody [C] & $\%$ & $\%$ & $\%$ & $\%$ \\
\hline Wet & $\mathrm{na}^{\mathrm{a}}$ & $47.5 \pm 0.8$ & $45.3 \pm 0.3$ & $48.3 \pm 0.6$ \\
\hline Ambient & na & $48.1 \pm 0.9$ & $44.7 \pm 0.4$ & $47.1 \pm 0.5$ \\
\hline Dry & na & $49.5 \pm 0.1$ & $44.8 \pm 0.4$ & $46.5 \pm 0.6$ \\
\hline Wood C stock & $\mathrm{g} \mathrm{C} \mathrm{m}^{-2}$ & $\mathrm{~g} \mathrm{C} \mathrm{m}^{-2}$ & $\mathrm{~g} \mathrm{C} \mathrm{m}^{-2}$ & $\mathrm{~g} \mathrm{C} \mathrm{m}^{-2}$ \\
\hline Wet & na & $\mathrm{na}^{\mathrm{b}}$ & $118 \pm 24$ & $122 \pm 16$ \\
\hline Ambient & na & na & $105 \pm 15$ & $96 \pm 11$ \\
\hline Dry & na & na & $214 \pm 39$ & $114 \pm 18$ \\
\hline
\end{tabular}

${ }^{a}$ na = not available. 1992 organic layers samples were archived after dry mass assessments, but damage by rodent activity while awaiting $\mathrm{C}$ analysis

b $\mathrm{C}$ stock not calculated for twigs in 1999 because twig [C] analyses were only done for a subset of tissues

These data are only for woody material less than $3 \mathrm{~cm}$ diameter

and the $15-30 \mathrm{~cm}$ layers across all treatments $(p<0.01)$. On average, C concentration in the 0-15 cm layer decreased from 3.5 to $2.8 \% \mathrm{C}$, which corresponded to a C loss of $0.7 \mathrm{~kg} \mathrm{~m}^{-2}$ over 13 years. In the $15-30 \mathrm{~cm}$ layer the decrease, from 0.6 to $0.5 \% \mathrm{C}(p=0.005)$, corresponded to a $\mathrm{C}$ loss of $0.1 \mathrm{~kg} \mathrm{~m}^{-2}$. Carbon concentrations in the $30-45 \mathrm{~cm}$ layer remained at $0.3 \% \mathrm{C}$ and did not change over the 13 years, whereas an increase through time was observed in the $45-60 \mathrm{~cm}$ layer from 0.20 to $0.25 \% \mathrm{C}(p=0.004)$, corresponding to $0.04 \mathrm{~kg} \mathrm{C} \mathrm{m}^{-2}$. 

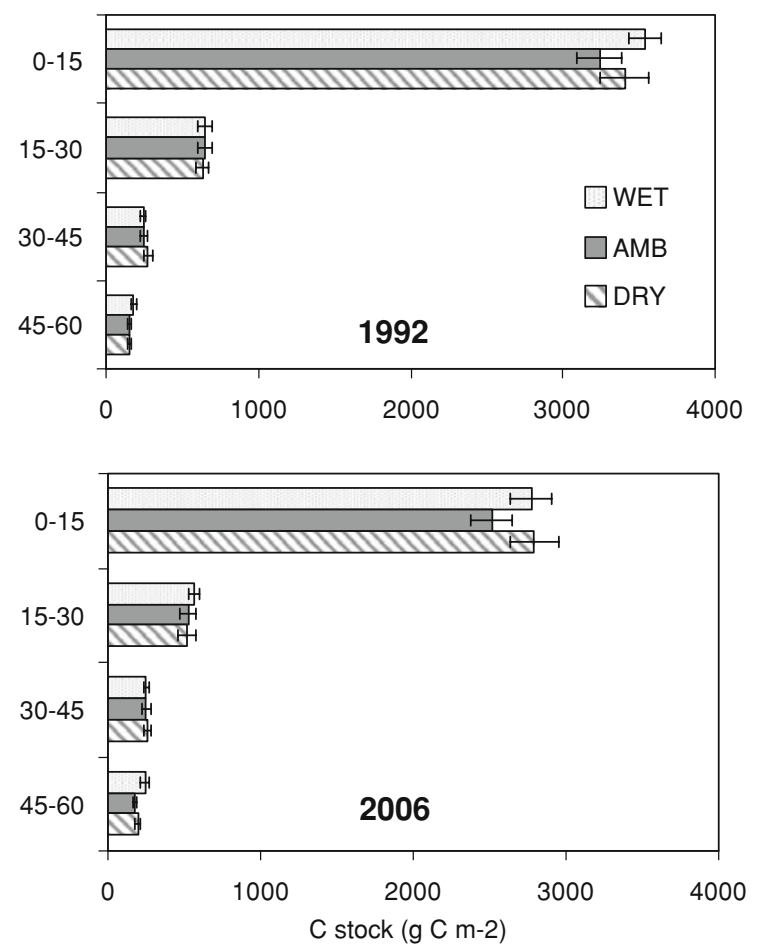

Fig. 2 Carbon stock $\left(\mathrm{g} \mathrm{C} \mathrm{m}^{-2}\right)$ per depth increment and treatment in 1992 and 2006. Error bars represent standard error. (Adapted from Johnson et al. 2008)

\section{Discussion}

Organic soil horizons

In the $\mathrm{O}$ horizon, treatment effects showed the highest C stocks in the dry treatment in 1999, 2004 and 2006, but not in 2002. The observed increase in $\mathrm{O}$ horizon mass of the dry plot is consistent with observations of higher production of leaf litter into the dry treatment (Hanson et al. 2003c). Pretreatment litterfall averaging approximately $500 \mathrm{~g} \mathrm{~m}^{-2}$ was similar across all three treatment areas. Starting in 1998, differences in litterfall inputs were evident (Hanson et al. 2003c) with litter inputs to the dry plots increasing by approximately $12 \%$ (i.e. $58 \mathrm{~g}$ dry mass $\mathrm{m}^{-2}$ ). In 2004 and 2005 dry plot litterfall differential production had reached +90 and $+116 \mathrm{~g} \mathrm{~m}^{-2}$ corresponding to a 16 and $25 \%$ increase, respectively, over the ambient and wet plot litterfall amounts (unpublished data). The higher leaf litter production at the dry plots was contrary to original hypotheses for the experiment
(Hanson et al. 2003c) which anticipated lower canopy leaf production with sustained drying. Increased leaf litter production was hypothesized to be caused by differences in element availability due to higher leaching under the wet treatment (Johnson et al. 2002). Simulations of the TDE treatments have shown that the changes in throughfall cause disproportionally large changes in soil water flux, with $-46 \%$ to $-59 \%$ and $+44 \%$ to $57 \%$ changes in water flux at the dry and wet plots, respectively (Johnson et al. 2002). Enhanced levels of acid water flux during the dormant season would leach plant essential elements from surface soils and could help explain the observed changes in litter production across treatments. In the final evaluation of post-treatment element status, however, Johnson et al. (2008) report on measured changes in soil element pools showing that the precipitation manipulations did not induce significant effects on soil $\mathrm{N}, \mathrm{SO}_{4}{ }^{2-}$, exchangeable $\mathrm{Ca}^{2+}$, $\mathrm{Mg}^{2+}$ and Bray- or bicarbonate extractable P. They did find a significant effect on exchangeable K. The significant $\mathrm{K}$ effect was expressed as increased $\mathrm{K}$ in the wet treatment area compared to the ambient and dry plots and was explained (at least in part) by the transfer of elements in throughfall from interception (dry) to distribution (wet) plots. A complete report and discussion of long-term effects of the TDE chronic precipitation manipulations on tree growth and leaf production are in progress.

Observed differences in $\mathrm{C}$ stocks between the dry treatment and the wet and ambient treatments of about $+40 \%$ corresponding to approximately $160 \mathrm{~g}$ in 2006 exceeds the differential mass inputs reported above. In addition, higher inputs of carbon would be expected to be reflected in the Oi rather than the Oe/ Oa horizon. We did not observed treatment-induced differences in Oi standing $\mathrm{C}$ stocks assessed 2-3 months after fresh litterfall input. These facts suggest that differences in litter inputs alone could not explain the observed differences in Oe/Oa $\mathrm{C}$ stocks developing with time. Reduction of $\mathrm{C}$ decomposition represents the other explanation.

Moisture is well known to influence the decomposition of organic matter and Hanson et al. (2003b) demonstrated site-specific relationships between soil water status and respiration for the TDE study showing lower respiration under dry conditions. When soil respiration was measured, however, significant treatment effects were seldom found, indicating that a 
differential wetting effect by itself was too small or transient to explain the differences in $\mathrm{C}$ stock. The throughfall measurements did not change the temporal distribution of rain events, only the intensity of throughfall reaching the forest floor during events and the timing of rain events may be as important as the amounts of precipitation for controlling the mineralization of organic matter (Curiel Yuste et al. 2003; Harper et al. 2005), suggesting that substantial differences in decomposition rates between treatments occurred only intermittently and therefore was not captured by manual soil respiration measurements. A long-term cumulative effect of small differences may, however, have contributed to the larger $\mathrm{C}$ pools at the dry plots.

Differences in $\mathrm{C}$ input to the $\mathrm{O}$ layer and differences in decomposition of the standing pool seem likely, but neither can explain the differences in observed $\mathrm{C}$ stocks on their own, suggesting that both mechanisms functioned together to produce significantly higher $\mathrm{C}$ stocks in the dry treatment. There is some support for this interpretation by modeling of the $\mathrm{C}$ in the forest floor with the site-specific standlevel computer model INTRASTAND (Hanson et al. 2004, 2005). A litter-cohort based version of the model operating at a daily time step over multiple years successfully predicted the direction, but not the magnitude, of observed response and suggests about $4 \%$ difference between dry and ambient due to dryer soil conditions and $12 \%$ difference due to difference in litterfall during the last years of the experiment. Total difference was $16 \%$ when both factors were taken into account in the model.

Substantial interannual variation in $\mathrm{Oi}$ and $\mathrm{Oe} / \mathrm{Oa}$ C stocks existed (Fig. 1). This might be partly explained by the difficulty of separating the different O horizons (Yanai et al. 2000), but the Oi and Oe/Oa separations are quite obvious for the Walker Branch soils and such error is not likely to account for the large mass differences measured. Sampling each year was done in transects along the direction of the slope, with each treatment being sampled in each transect, thus minimizing the risk of bias between treatments. Inter-annual variations in organic layer moisture conditions represent another realistic source of variation. Parallel observations from another study on the Oak Ridge Reservation (CT Garten, pers. comm.) also confirm the possible magnitude of organic layer $\mathrm{C}$ stocks for this ecosystem. Future research and improved models of soil carbon cycling including measures of $\mathrm{C}$ inputs and the dynamic nature of decomposition processes will help resolve the reasons for observed changes in organic horizon carbon stocks with chronic precipitation change.

Implications of changing element stocks

The sequestration of elements in addition to $\mathrm{C}$ that takes place during the accumulation of organic layer mass has implications for plant growth. Organic matter accumulation immobilizes plant essential elements needed for tree growth. Are the levels of element immobilization associated with these reported levels of carbon accumulation a problem? To evaluate this question, annual element demands of the Walker Branch forest (Table 3) were calculated from annual net primary production estimates (Hanson et al. 2003d). This budget indicates that immobilization, leading to element limitation is probably not a problem with respect to nitrogen, but it could be an issue for some base cations. The cumulative, multi-year amount of nitrogen immobilized within the dry plot organic layers (difference in $\mathrm{N}$ stock between dry and ambient/wet in the $\mathrm{O}$ horizon) is approximately $6 \mathrm{~g} \mathrm{~N} \mathrm{~m}^{-2}$ in 2006, or approximately $0.43 \mathrm{~g} \mathrm{~m}^{-2} \mathrm{yr}^{-1}$, smaller than the amount supplied to the forest annually in wet and dry $\mathrm{N}$ deposition for Walker Branch $\left(\sim 1.0 \mathrm{~g} \mathrm{~N} \mathrm{~m}^{-2} \mathrm{yr}^{-1}\right.$, Table 3) and also smaller than the net annual requirement of $\mathrm{N}$ for tree growth. However, for $\mathrm{K}, \mathrm{Ca}$ and $\mathrm{Mg}$ the immobilization caused by accumulation of organic matter is not replenished by deposition (Table 3). Previous studies on Walker Branch (e.g. Johnson et al. 1988) reported small pools of exchangeable and total $\mathrm{Ca}$, suggesting that $\mathrm{Ca}$ limitation may be a future problem at the site. Cumulative, multi-year immobilization of $\mathrm{Ca}$ was found to be on the order of $11.4 \mathrm{~g} \mathrm{Ca} \mathrm{m}^{-2}$ (Table 3), or about $1 \mathrm{~g}$ $\mathrm{Ca} \mathrm{m}^{-2} \mathrm{yr}^{-1}$. Annual atmospheric inputs of $0.13 \mathrm{~g} \mathrm{Ca}$ $\mathrm{m}^{-2} \mathrm{yr}^{-1}$ do not match this demand. Rooted plants at this site, however, may have access to $\mathrm{Ca}$ in the dolomite bedrock or less-weathered soil (Grigal and Ohmann 2005). In addition, sustained higher litter production in the dry treatment since 1998 (Hanson et al. 2003c) suggests that element immobilization is currently not a problem for leaf production. Nevertheless, stem growth is a lower priority carbon sink and might be expected to demonstrate effects of element limitations first. 
Table 3 Annual element budget of uptake, translocation and requirement of macro-elements at TDE

\begin{tabular}{|c|c|c|c|c|c|c|}
\hline NPP component & $\mathrm{C}$ & $\mathrm{N}$ & $\mathrm{P}$ & $\mathrm{K}$ & $\mathrm{Ca}$ & $\mathrm{Mg}$ \\
\hline \multicolumn{7}{|c|}{ Annual element needs $\left(\mathrm{g} \mathrm{m}^{-2} \mathrm{yr}^{-1}\right)$} \\
\hline Leaf growth (litter) & 241.8 & 3.6 & 0.22 & 1.4 & 7.2 & 0.8 \\
\hline Leaf growth (green) & 276.5 & 10.0 & 0.61 & 5.5 & 4.4 & 0.9 \\
\hline Flower parts & 10.9 & 0.5 & 0.04 & 0.1 & 0.2 & 0.0 \\
\hline Wood & 315.6 & 0.8 & 0.09 & 0.7 & 1.1 & 0.1 \\
\hline Sapling & 7.8 & 0.0 & 0.00 & 0.0 & 0.0 & 0.0 \\
\hline Bark & 9.9 & 0.1 & 0.00 & 0.0 & 0.6 & 0.0 \\
\hline Coarse roots & 12.0 & 0.1 & 0.01 & 0.1 & 0.3 & 0.0 \\
\hline Fine roots & 153.1 & 2.3 & 0.20 & 1.3 & 2.4 & 0.6 \\
\hline Total Requirement & & 13.9 & 0.95 & 7.7 & 9.0 & 1.7 \\
\hline Uptake & & 7.6 & 0.57 & 3.6 & 11.8 & 1.5 \\
\hline Translocation & & 6.3 & 0.38 & 4.1 & -2.8 & 0.2 \\
\hline $\begin{array}{l}\text { Net annual requirem } \\
\text { (Wood + bark + coar }\end{array}$ & $\begin{array}{l}\text { se wood) } \\
\text { se }\end{array}$ & 1.1 & 0.11 & 0.8 & 2.0 & 0.1 \\
\hline Organic layer 2006 & $\mathrm{C}\left(\mathrm{g} \mathrm{C} \mathrm{m}^{-2}\right)$ & $\mathrm{N}\left(\mathrm{g} \mathrm{N} \mathrm{m}^{-2}\right)$ & $\mathrm{P}\left(\mathrm{g} \mathrm{P} \mathrm{m}^{-2}\right)$ & $\mathrm{K}\left(\mathrm{g} \mathrm{K} \mathrm{m}^{-2}\right)$ & $\mathrm{Ca}\left(\mathrm{g} \mathrm{Ca} \mathrm{m}^{-2}\right)$ & $\operatorname{Mg}\left(\mathrm{g} \mathrm{Mg} \mathrm{m}^{-2}\right)$ \\
\hline \multicolumn{7}{|c|}{ Element pool size $2006\left(\mathrm{~g} \mathrm{~m}^{-2}\right)$} \\
\hline \multicolumn{7}{|l|}{ Oi } \\
\hline Wet & 174 & 3.6 & 0.20 & 0.6 & 5.2 & 0.3 \\
\hline Ambient & 138 & 3.0 & 0.16 & 0.5 & 4.9 & 0.4 \\
\hline Dry & 164 & 3.1 & 0.18 & 0.8 & 5.5 & 0.5 \\
\hline Mean & 159 & 3.2 & 0.18 & 0.7 & 5.2 & 0.4 \\
\hline \multicolumn{7}{|l|}{$\mathrm{Oe} / \mathrm{Oa}$} \\
\hline Wet & 435 & 14.4 & 0.80 & 2.0 & 17.6 & 1.1 \\
\hline Ambient & 407 & 14.5 & 0.84 & 2.4 & 20.5 & 1.6 \\
\hline Dry & 597 & 20.8 & 1.19 & 3.8 & 31.9 & 2.3 \\
\hline Mean & 480 & 16.6 & 0.94 & 2.7 & 23.3 & 1.7 \\
\hline \multicolumn{7}{|c|}{ Annual deposition $\left(\mathrm{g} \mathrm{m}^{-2}\right)$} \\
\hline & - & 1.0 & - & 0.03 & 0.13 & 0.03 \\
\hline
\end{tabular}

Definition of total requirement, uptake and translocation according to those of Cole and Rapp (1981). Deposition data were obtained from http://www.epa.gov/castnet/, http://mercury.ornl.gov/and Hanson et al. (1989)

Mineral soil horizons

As noted previously (Johnson et al. 2008), there was no treatment-induced change in mineral soil C stocks during the course of the 13 year experiment, despite substantial differences in litter input between treatments starting in 1998 (Hanson et al. 2003c). Differences in mineralization rates under the imposed moisture regimes, which may be an explanation for the treatment effects in the Oe/Oa horizon apparently did not extend to measurable effects on mineral soil during the 13 years of experimental treatments. A lack of response to increased litter input was however not unexpected. The $\mathrm{C}$ input to the mineral soil from canopy litter has been demonstrated to be very limited at Walker Branch over sub-decadal time periods (Swanston et al. 2005; Fröberg et al. 2007). ${ }^{14} \mathrm{C}$ data from the TDE site, reported by Gaudinski and Trumbore (2003), showed that the turnover time in the Oe/ Oa horizon was $10 \pm 5$ years and in the A horizon 91 and 189 years respectively for carbon in low- and high-density fractions, with the low density fraction dominating $\mathrm{C}$ stocks. In the $\mathrm{E}$ horizon turnover times were 83 and 435 years, respectively for the same fractions, where the high-density fraction was larger than the low density fraction. These long turnover times for $\mathrm{C}$ in the mineral soil indicate that $\mathrm{C}$ pools are stable and therefore not very dynamic. The long turnover 
times furthermore supports low inputs to the mineral soil from fresh litter. Both factors: stable $\mathrm{C}$ stored in the mineral soil and limited inputs of fresh carbon imply that response to changes in climate is slow and in accordance with the results presented here.

The large temporal change in soil C concentrations and stock in the mineral soil observed from 1992 through 2006 under all treatments is remarkable, but not unprecedented in the literature. Kelly and Mays (2005) reported an even larger absolute change (albeit an increase) in C stocks for a site in Central Tennessee, with $\mathrm{C}$ concentration increase from on average $2.1 \%$ to $3.6 \%$ in the top $10 \mathrm{~cm}$ of the mineral soil between 1976 and 2002. The decrease in $\mathrm{C}$ stocks measured at the TDE was similar to those reported by Bellamy et al. (2005) for soils all across England. It is important to interpret this large trend in the data with care, especially because the TDE soil sampling protocol used two different auger methods in 1992 and 2006. Increasing temperature trends at the site which do exist (data not shown) and our current models of soil carbon cycling were not capable of explaining this trend, and annual resolution measurements of belowground root litter inputs do not exist from which to evaluate that contribution to surface soil $\mathrm{C}$ pools. We were thus not able to satisfactory explain the trend. These data will be archived along with other TDE measurements for further analysis and future explanation by interested members of the scientific community.

\section{Conclusion}

Results from this study highlight some of the interactions between climate, pedology, element cycling, vegetation cover and $\mathrm{C}$ stocks. Effects of climate change are likely to lead to changes in tree phenology and soil properties, which may have long-term effects on $\mathrm{C}$ stocks. Here we demonstrated that, over the course of 13 years, a shift in precipitation amounts produced changes in soil $\mathrm{C}$ stocks in the $\mathrm{O}$ horizon. This was explained by a combination of higher litter input and slower decomposition in the dry treatment, leading to higher $\mathrm{C}$ stocks. Over multiple decades and centuries these effects may prove to be transient with other effects on the ecosystem, such as changes in vegetation revealing themselves to be more important for $\mathrm{C}$ stocks in the long run. The data presented here nevertheless do lead to the conclusion that for this ecosystem and on a decadal scale, changing climates leading to dryer conditions will increase $\mathrm{C}$ stocks in the $\mathrm{O}$ horizon.

Acknowledgements We acknowledge support from the U.S. Department of Energy (DOE), Office of Science, Biological and Environmental Research (BER) program as part of the Program for Ecosystem Research (PER). Oak Ridge National Laboratory is managed by UT-Battelle, LLC, for the DOE under contract DE-AC05-00OR22725.

Open Access This article is distributed under the terms of the Creative Commons Attribution Noncommercial License which permits any noncommercial use, distribution, and reproduction in any medium, provided the original author(s) and source are credited.

\section{References}

Aber JD, Melillo JM, Nadelhoffer KJ et al (1991) Factors controlling nitrogen cycling and nitrogen saturation in northern temperate forest ecosystems. Ecol Appl 1:303-315

Bellamy PH, Loveland PJ, Bradley RI, Lark RM, Kirk GJD (2005) Carbon losses from all soils across England and Wales 1978-2003. Nature 437:245-248

Borken W, Savage K, Davidson EA, Trumbore SE (2006) Effects of experimental drought on soil respiration and radiocarbon efflux from a temperate forest soil. Glob Chang Biol 12:177-193

Christensen JH, Hewitson B, Busuioc A et al (2007) Regional climate projections. In: Solomon SD, Qin M, Manning Z et al (eds) Climate change 2007: the physical science basis. Contributions from working group I to the fourth assessment report of the international panel on climate change. Cambridge University Press, Cambridge, UK and New York, USA, pp 847-940

Cole DW, Rapp M (1981) Elemental cycling in forest ecosystems. In: Reichle DE (ed) Dynamic properties of forest ecosystems. Cambridge University Press, London, UK, pp 341-409

Curiel Yuste J, Janssens IA, Carrara A, Meiresonne L, Ceulemans R (2003) Interactive effects of temperature and precipitation on soil respiration in a temperate maritime forest. Tree Physiol 23:1263-1270

Dress WJ, Boerner REJ (2001) Root dynamics of southern Ohio oak-hickory forests: influences of prescribed fire and landscape position. Can J Forest Res 31:644-653

Eberhardt LL, Thomas JM (1991) Designing environmental field studies. Ecol Monogr 61:53-73

Fröberg M, Jardine PM, Hanson PJ, Swanston CJ, Todd DE, Tarver JR, Garten CT (2007) Low dissolved organic carbon input from fresh litter to deep mineral soils. Soil Sci Soc Am J 71:347-354

Garten CT, Huston MA, Thoms CA (1994) Topographic variation of soil-nitrogen dynamics at walker branch watershed, Tennessee. For Sci 40:497-512

Gaudinski JB, Trumbore SE (2003) Soil carbon turnover In: Hanson PJ, Wullschleger SD (eds) North American temperate deciduous forest responses to changing precipitation 
regimes. Ecol Stud, vol 166. Springer, New York, pp 190209

Grigal DF, Ohmann PR (2005) Calcium and forest systems: diffusion from deep sources. Soil Sci 170:129-136

Hanson PJ, Rott K, Taylor GE Jr, Gunderson CA, Kindberg SE, Ross-Todd BM (1989) $\mathrm{NO}_{2}$ deposition to elements representative of a forest landscape. Atmos Environ 23:17831794

Hanson PJ, Todd DE, Edwards NT, Huston MA (1995) Field performance of the Walker branch throughfall displacement experiment. In: Jenkins A, Ferrier RC, Kirby C (eds) Ecosystem manipulation experiments: scientific approaches, experimental design and relevant results. Ecosystem Research Report No. 20, Commission of the European Communities, pp 307-313

Hanson PJ, Todd DE, Amthor JS (2001) A six year study of sapling and large-tree growth and mortality responses to natural and induced variability in precipitation and throughfall. Tree Physiol 21:345-358

Hanson PJ, Huston MA, Todd DE (2003a) Walker branch throughfall displacement experiment (TDE) In: Hanson PJ, Wullschleger SD (eds) North American temperate deciduous forest responses to changing precipitation regimes. Ecol Stud, vol 166. Springer, New York, pp 8-31

Hanson PJ, O’Neill EG, Chambers MLS, Riggs JS, Joslin JD, Wolfe MH (2003b) Soil respiration and litter decomposition. In: Hanson PJ, Wullschleger SD (eds) North American temperate deciduous forest responses to changing precipitation regimes. Ecol Stud, vol 166. Springer, New York, pp 163-189

Hanson PJ, Todd DE, Joslin JD (2003c) Canopy production decomposition In: Hanson PJ, Wullschleger SD (eds) North American temperate deciduous forest responses to changing precipitation regimes. Ecol Stud, vol 166. Springer, New York, pp 303-315

Hanson PJ, Edwards NT, Tschaplinski TJ, Wullschleger SD, Joslin JD (2003d) Estimating the net primary and net ecosystem production of a southeastern upland Quercus forest from an 8-year biometric record. In: Hanson PJ, Wullschleger SD (eds) North American temperate deciduous forest responses to changing precipitation regimes. Ecol Stud, vol 166. Springer, New York, pp 378-395

Hanson PJ, Amthor JS, Wullschleger SD et al (2004) Oak forest carbon and water simulations: model intercomparisons and evaluations against independent data. Ecol Monogr 74:443-489

Hanson PJ, Wullschleger SD, Norby RJ, Tschaplinski TJ, Gunderson CA (2005) Importance of changing $\mathrm{CO}_{2}$, temperature, precipitation, and ozone on carbon and water cycles of an upland oak forest: incorporating experimental results into model simulations. Glob Chang Biol 11:1402-1423

Harper CW, Blair JM, Fay PA, Knapp AK, Carlisle JD (2005) Increased rainfall variability and reduced rainfall amount decreases soil $\mathrm{CO}_{2}$ flux in a grassland ecosystem. For Ecol Manage 138:273-283
Heimann M, Reichstein M (2008) Terrestrial ecosystem carbon dynamics and climate feedbacks. Nature 451:289-292

Hurlbert SH (1984) Pseudoreplication and the design of ecological field experiments. Ecol Monogr 54:187-211

Hyvönen R, Ågren GI, Linder S et al (2007) The likely impact of elevated $\left[\mathrm{CO}_{2}\right]$, nitrogen deposition, increased temperature and management on carbon sequestration in temperate and boreal forest ecosystems: a literature review. New Phytol 173:463-480

Johnson DW, Van Hook RI (1989) Analysis of biogeochemical cycling processes in Walker Branch Watershed. SpringerVerlag, New York

Johnson DW, Henderson GS, Todd DE (1988) Changes in nutrient deposition in forests and soils of Walker Branch Watershed, Tennessee, over an eleven-year period. Biogeochem 5:275-293

Johnson DW, Hanson PJ, Todd DE Jr (2002) The effects of throughfall manipulation on soil leaching in a deciduous forest. J Environ Qual 31:204-216

Johnson DW, Todd DE Jr, Hanson PJ (2008) Effects of throughfall manipulations on soil nutrient status: results of 12 years of sustained wet and dry treatments. Glob Chang Biol 14:1661-1675

Joslin JD, Wolfe MH (1998) Impacts of water input manipulations on fine root production and mortality in a mature hardwood forest. Plant Soil 204:165-174

Kelly JM, Mays PA (2005) Soil carbon changes after 26 years in a Cumberland Plateau hardwood forest. Soil Sci Soc Am J 69:691-694

Loehle C, LeBlanc D (1996) Model-based assessments of climate change effects on forests: a critical review. Ecol model 90:1-31

Meehl GA, Stocker TF, Collins P et al (2007) Global climate projections. In: Solomon SD, Qin M, Manning Z et al (eds) Climate change 2007: the physical science basis. Contributions from working group I to the fourth assessment report of the international panel on climate change. Cambridge University Press, Cambridge, UK and New York, USA, pp 747-845

Mikha MM, Rice CW, Milliken GA (2005) Carbon and nitrogen mineralization as affected by drying and wetting cycles. Soil Biol Biochem 37:339-347

Reichstein M, Rey A, Freibauer A et al (2003) Modeling temporal and large-scale spatial variability of soil respiration from soil water availability, temperature and vegetation productivity indices. Global Biogeochem Cycles 17:Art. No. 1104

Swanston CW, Torn MS, Hanson PJ, Southon JR, Garten CT, Hanlon EM, Ganio L (2005) Initial characterization of processes of soil carbon stabilization using forest stand-level radiocarbon enrichment. Geoderma 128:52-62

Yanai RD, Arthur MA, Siccama TG, Federer CA (2000) Challenges of measuring forest floor organic matter dynamics: repeated measures from a chronosequence. For Ecol Manage 138:278-283 